\title{
THE IMPACT OF MATURITY REGULATION ON HIGH INTEREST RATE LENDERS AND BORROWERS $\dagger$
}

\author{
George J. BENSTON* \\ University of Rochester, Rochester, NY 14627, USA
}

Received March 1976, revised version received May 1976

The State of Maine recently imposed an additional regulation on the maturity of small loans offered by finance companies, presumably to protect the consumer. They effectively restricted the maturity of these high interest rate loans to 36 months. Within five years, the number of licensees (finance company offices) declined from 116 to 24 . Within another five years, all of these lenders had completely ceased operations. Hypotheses on the effect and value to consumers of the regulation are stated operationally and tested empirically. This study includes estimation of the loan companies' cost function, (accounting) profit rates and output and a survey of the individuals directly affected by the demise of the companies. The analysis indicates (1) that the maturity restriction made ordinary operations unprofitable, (2) why this occurred, and (3) that half of the consumers did not obtain funds elsewhere.

\section{Borrowing controls and consumer welfare}

Perhaps because of the continuing influence of the Old Testament, Aristotle and medieval Christianity, ${ }^{1}$ many people and governments do not regard interest simply as a price paid for a good or service. Although few people today believe that charging interest for the use of money is immoral, our laws and regulations reflect the still-held belief that people ought not to pay more than a given rate of interest and ought not to borrow without restrictions. As a consequence, state usury and small loan laws restrict the amount that can be charged and the maximum amount that can be loaned to individuals.

Limitations on the time over which a 'high rate' lender (consumer finance company) may extend loans to a consumer is the most recent regulation imposed

$\dagger$ Journal of Financial Economics 4 (1977) 23-49. (1) North-Holland Publishing Company

*Professor, Graduate School of Management and Center for Research in Government Policy and Business, University of Rochester. Research for this paper was supported by the National Commission on Consumer Finance. Additional support was provided by the Institute for Humane Studies. Thanks are due to Neil Murphy, James Kershner and Dan Sullivan of the University of Maine who supervised and conducted the survey of borrowers; Richard Poulos and Gerald Cope, who provided background documents; the finance companies and the State of Maine Banking Department, who generously provided data; and Kim Benston and Joe Safier, who aided in research. Of course, they are not responsible for and may not agree with the paper.

${ }^{1}$ See Taeusch (1942). 
by those who wish to protect consumers from presumably rapacious lenders. These 'consumer advocates' believe that many consumer finance companies, which are permitted to charge rates averaging about 24 percent, deliberately keep their clients in debt continuously. Richard Poulos, Federal Referee in Bankruptcy for the Southern District of Maine and perhaps the most forceful proponent of legislation restricting the period of indebtedness to small loan companies, puts the argument as follows:

High interest has always plagued civilization. Most regulation has concentrated on controlling the rate of interest by setting maximum statutory limits. But this is not enough. Any problems about interest must be resolved by also considering (1) the amount of the loan and (2) the length of time for which it was granted. And the effectiveness of whatever restrictions may exist as far as these two factors are concerned must be tested against their possible evasion by the device of renewals.

Loans for short terms, even at high rates of interest, are not overly burdensome for most poor persons. The cost to meet some monetary emergency by a loan of one or two years is not exorbitant. But no one, let alone a low income person, can long endure (1) high rates of interest (2) on relatively large amounts of indebtedness (3) over long periods of time, from 3-8 years or more.

Renewals soon convert short term loans into long term obligations thereby subjecting the debtor to economic slavery. This has the effect of diverting large amounts of money from a debtor's limited income merely for the purpose of paying interest, thus hampering him from meeting the basic necessities of life for himself and his family. His financial strength is sapped to a point where any common hazard of life such as illness, loss of employment, divorce, etc., inevitably leads to a personal financial catastrophe compelling him to seek relief from welfare agencies or, ultimately, from the bankruptcy court. (Undated, pp. 24-25)

In large measure because of the efforts of Mr. Poulos and other 'consumer advocates', the State of Maine adopted a law in 1967 which reduces the maximum interest rate that finance companies could charge to 8 percent on any loan balance remaining unpaid after 36 months. While this legislation probably benefited and may have been supported by the finance companies' competitors (commercial banks, credit unions, loan sharks, etc.), the principal proponents appear motivated primarily by a desire to help consumers. Whether or not the law served this purpose is the subject of the analysis which follows. The situation in Maine provides us with a valuable 'laboratory experiment' from which the effects of such restrictive legislation can be measured and evaluated before it is extended to other jurisdictions. 
The analysis is presented in four additional sections. The next section describes the effect on finance companies in Maine of the law which limited small loan maturities to 36 months. Hypotheses about the reasons for the dramatic decline in finance company offices and assets and the effect of this decline on consumers are delineated in the balance of the section. Tests of the hypothesis are developed and reported in sections 3 and 4. Section 3 analyzes hypotheses concerning the effect of the restrictive legislation on finance company operations, while section 4 investigates its impact on the availability of consumer credit. Section 5 presents data to test hypotheses about the characteristics of longterm borrowers, those whom the legislation is designed to protect. The study and findings are summarized in the last section.

\section{Hypotheses on the effect of 'limiting' small loan maturities to 36 months}

\subsection{Conditions obtaining before and after the law}

Maine's 8 percent limitation on the interest consumer finance companies can charge on loan balances unpaid after 36 months has been very strictly applied. The maturity of a loan is dated from its inception; extensions, rewritings and additional cash advances are not considered new loans. Nor can the effects of the 'limitation' be avoided by splitting loans, since this practice previously was (and still is) prohibited. The consequences attending the law have been considerable.

At the time the law was passed (1967), 116 offices (licences) were operated by 28 finance companies in the state (as of June 30th). In 1965, 111 offices had been operated by 27 companies. By June 1972 the number had decreased to 24 offices operated by 9 companies and by June 1975 the number had decreased further to 14 offices operated by 6 companies. By 1977 all consumer finance companies will have closed. As fig. 1 shows, the reduction in offices and companies occured primarily since 1969 , the year in which the legislation affected the companies' loan portfolios and the year in which most companies realized that they were unlikely to succeed in getting the ' 36 month limitation' repealed or modified. Similarly, the dollar amount of loans outstanding fell from \$31.0 million in December 1967 to $\$ 10.8$ million in December 1971. (Later data are not available.)

\subsection{Proponents' hypotheses}

While proponents of the law did not expect the dramatic decline experienced, they consider the situation a net benefit for consumers. ${ }^{2}$ These consumer advocates believe that the finance companies had been making exorbitant and im-

\footnotetext{
${ }^{2}$ Quotations and sources of the viewpoints summarized are given in Benston (1974b).
} 
moral profits and view their departure as proof that they are not satisfied with normal returns. As they see it, the ' 36 month limitation' reduces the finance companies' revenues by preventing them from 'exploiting' consumers: no longer can they entice consumers into renewing loans or compound more than 60 days unpaid interest in contravention of law. ${ }^{3}$

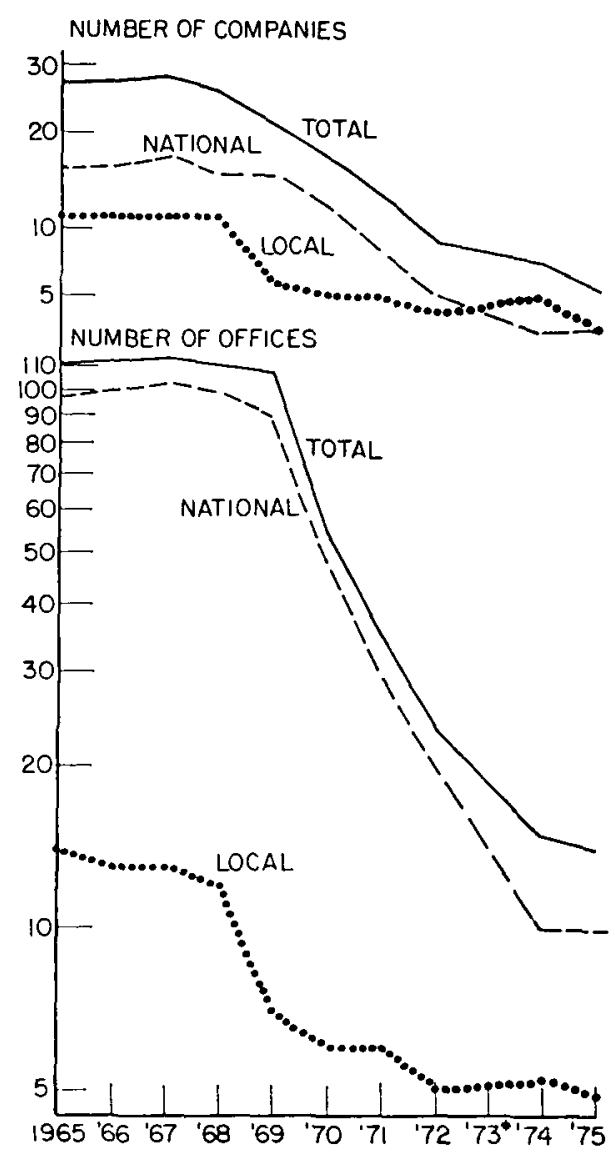

Fig. 1. Number and total, national and local companies and offices operating in Maine, as of June 20, 1965 through 1972. (*1973 data not available.)

Some supporters of the law also believe that national companies pulled out of Maine to 'teach the state a lesson' and show other states that restrictive legislation means losing the small loan companies. They argue that the national companies find foregoing 'normal' profits a price well worth paying to administer

${ }^{3}$ The law permits lenders to add no more than 60 days unpaid interest to the principal on which additional interest is compounded. A 'renewal' creates a new loan to which another 60 days unpaid interest can be added to principal. 
this lesson. However, the data presented in fig. 1 refutes this hypothesis. The decline in the number of national and local companies and their offices was about the same. Indeed, local companies appear to have ceased operations sooner.

A somewhat different 'business' explanation for the decline in the number of finance companies is that the companies simply closed some of their offices to achieve economies of scale. As a consequence, it is argued, larger companies could operate at lower costs and thus 'live' with the new legislation.

In any event, the consumer advocates believe that consumers were not seriously inconvenienced by the decline in finance company lending. Quite the contrary, they view the increase in credit union loans from $\$ 166$ million in December 1967 to $\$ 225$ million in December 1971 as evidence that borrowers were being served effectively by lower rate lenders and that, consequently, they benefited from the legislation.

\subsection{Opponents' hypotheses}

Opponents of the legislation believe that the virtual elimination of consumer finance companies is due primarily to the negative effect of the ' 36 month limitation' on ordinary operating expenses and revenue. The law not only effectively prohibits them from making loans with maturities longer than 36 months (since the 8 percent they are permitted to charge is about the same rate at which they obtain the funds loaned, leaving nothing for operating expenses and losses); it also makes renewals past this limit very unprofitable. This prohibition, the companies claim, does not allow them to serve regular customers or extend the term of a loan on which a borrower is unable to make scheduled payments. ${ }^{4}$ Consequently, the small loan company cannot renew or extend loans, but must limit its operations to making one-time loans. ${ }^{5}$

The companies deny the consumer advocates' belief that they should be able to make normally profitable one-time loans with maturities of less than 36 months. Operating expenses are higher under such restrictions, they claim. Lending to a present borrower is much less expensive than lending to a new customer: The credit check required is much less extensive, the interview need not be as long and, most important, the risk is less since the present customer's

\footnotetext{
${ }^{4}$ As one company vice-president puts it in correspondence with the author: 'Each time the borrower refinances his loan with the lender, the term of the loan becomes shorter and the monthly payment larger than the payment on the previous loan. Eventually, because of the 36 month limitation that dates from the initial loan, the term of the loan becomes so short and the payment so large that the lender can no longer serve the borrower's needs since he is unable to make the big payment each month.'

${ }^{5}$ While data on the percentage of loans made to present customers are not reported to the Bank Commissioner in Maine, data from large companies and from other states indicate that about 62 percent of the number of loans made are renewals (with and without cash added), about 27 percent are made to new borrowers, and 11 percent to former borrowers.
} 
payment record is known. The cost of acquiring customers also increases if lending to present customers is made prohibitively unprofitable. In addition, the law creates much higher collection costs and loan losses. When a customer cannot make his payments, the usual practice is to reduce the size of the payments and extend the term of the loan. With this practice made unprofitable, the companies must formally declare the loan in default and obtain a court judgment, a more expensive procedure for both companies and customers.

Finally, opponents of the law question the claim that consumers are served better when one source of supply, finance companies, is eliminated as a competitor for consumers' trade. While some borrowers may be served better by commercial banks and credit unions, others may not be able to borrow from legal lenders at all.

\subsection{Summary of hypotheses}

In summary, the following hypotheses are proposed by proponents and opponents of the ' 36 month limitation':

\section{Proponents}

(1) Finance companies were making abnormal and immoral returns before the penalty on maturities over 36 months was imposed, and now they are not satisfied with normal returns.

(2) Abnormal, immoral revenue was generated by tempting consumers into making improvident loans which they couldn't repay and had to renew.

(3) National companies suspended operations to 'teach Maine and other states a lesson' (this hypothesis is rejected by fig. 1).

(4) Economies of scale, rather than the adverse effects of the law, led the companies to close and consolidate offices.

(5) In any event, consumers were benefited, not hurt, because they were able to obtain loans at credit unions and other lower rate lenders.

\section{Opponents}

(1) The 8 percent maximum rate on balances outstanding more than 36 months decreases average gross yields intolerably.

(2) Renewals are no longer profitable, and new customers require higher acquisition and operating expenses.

(3) Since extensions of loans to borrowers in default is very costly when the balance earns only 8 percent gross, companies are forced to attempt to collect these loans rather than 'work with' the customer.

(4) Consumers are worse off when an important source of credit is no longer available. 
In large measure, then, the alternative positions are based (1) on assumptions about the loan companies' revenue, expenses, and return on capital and (2) on the effects of the drastic decline in finance company lending on consumers. To put these viewpoints into perspective and render them testable, a descriptive model is presented in section 3 of the revenue and costs that a profit-maximizing lender faces when deciding whether or not to grant a loan. With this model, the effect of the maturity and other restrictions on the lender's decision-making function can be shown. With the important parameters of the model estimated, a test of the alternative hypotheses about loan company behavior can be made. Hypotheses on the availability of credit to consumers are considered in section 4 .

\section{Tests of hypotheses on finance company revenue and costs}

\subsection{Revenue and costs from small loans}

In deciding the level of its loan portfolio in a particular location or state, and whether or not to grant a loan to a specific individual, a consumer finance company must estimate the net cash flow that will be generated. With respect to the individual borrower, the company faces a certain outflow of the net cash loaned, the operations cost of processing the required papers, an uncertain inflow of payments, and the additional operations cost of processing the payments. Simply accepting payments and making bookkeeping entries is a small part of the expense of serving a customer. The type of customer who borrows from finance companies requires more personal time and resource-consuming attention than customers who borrow from commercial banks or credit unions. This is part of the product he purchases. Were this attention not given, the probability of non-payment would increase.

As with investments generally, there is an optimal level of resources for 'servicing' loans. At some point, the present value of greater expected amounts of payments is exceeded by the present value of additional expenditures on servicing. In general, if the expected net present value is not positive, the company will not make the loan. And where the state enforces a ceiling on the amount of interest and fees that can be charged, neither the company nor the borrower has the option of increasing the gross amount of cash inflow.

Nevertheless, a loan may be made to a borrower for whom an initial loan appears unprofitable (negative expected net cash flow) if the company expects a profitable long-term relationship with him. Several factors lead to this expectation. First, the operations cost of extending a second or additional loan may be less than the cost of a new loan because the company already has established records for the borrower. Second, the company obtains information about the probability of repayment and the cost of servicing in the course of lending, information purchased at the cost of a negative expected present value cash flow from the first loan. However, this may be a profitable investment if 
the company is able to reduce its expected losses and the 'excessive' operations cost of dealing with initially 'unprofitable' customers by granting small first loans from which it determines the best prospects for larger second loans. Finally, although a company might find loans under a given dollar size unprofitable (since gross income is determined by a ceiling rate per dollar while operating costs are primarily a function not of the dollar amount loaned but of servicing the customer), it might be willing to make these loans as 'loss leaders'. If, in the company's experience, first-time borrowers tend to make larger successive loans that are profitable, it would be willing to make individually unprofitable first loans. By making the customer a first loan, the company expects a high proportion of customers to borrow from it again because satisfaction with the service and/or inertia keeps them from changing to other lenders, even lower-cost lenders such as commercial banks or credit unions.

However, before these complex possibilities are structured and specified, the direct effect of the law on revenue is analyzed.

\subsection{Effect of the ' 36 month limitation' on revenue}

Reduction of revenue is an obvious effect of the law restricting gross interest yields to 8 percent on balances outstanding more than 36 months. The law, in effect, reduces the ceiling rate on loans to a weighted average of loans outstanding less and more than 36 months. The magnitude of this effect can be determined by calculating the average gross yield $(A)$ on loans of different maturities, with the following formula: ${ }^{6}$

$$
(1+A)^{p+u}=(1+P)^{p}(1+U)^{u},
$$

$P=$ profitable (higher) rate allowed up to 36 months,

$U=$ unprofitable ( 8 percent) rate allowed after 36 months,

$p=$ number of periods remaining at rate $P$,

$u=$ number of subsequent periods at rate $U$.

Solving eq. (1) for $A$ yields

$$
A=\left[(1+P)^{p}(1+U)^{u}\right]^{1 / p+u}-1 .
$$

Values for $A$ show one extreme effect of the law, since it is the average gross yield on funds outstanding over the entire period, $p+u$. The average gross yield also can be calculated on the assumption that a loan is repaid in equal periodic amounts. In this event, $A$ is calculated from eq. (3):

$$
\frac{(1+A)^{p+u} A}{(1+A)^{p+u}-1}=\frac{(1+P)^{p}(1+U)^{u}}{\sum_{i=0}^{u-1}(1+U)^{i}+(1+U)^{u} \sum_{j=0}^{p-1}(1+P)^{j}} .
$$

${ }^{6} \mathrm{I}$ am indebted to Marshall Freimer for discussions that clarified and simplified the following analysis. 
Table 1, part A shows the average rate, $A$, on funds not repaid until the end of the period $p+u$ of various combinations of years over which a loan earns profitable gross yields, $P$, of 30 and 24 percent and an unprofitable gross yield, $U$, of 8 percent. Part B of table 1 shows the average rate, $A$, on a loan repaid in equal installments over the period, $p+u$. Thus a finance company can expect a loan made for 3 years at 24 percent, but outstanding for an additional 1, 2 or 3 years will earn an average yield of 20 percent, 17 percent, and 16 percent. If this loan is repaid in equal installments over a 4, 5, or 6 year period, the

Table 1

Average gross yields assuming profitable yields $(P)$ of 30 and 24 percent and unprofitable yield $(U)$ of 8 percent, over combinations of three year periods.

\begin{tabular}{|c|c|c|c|c|c|c|}
\hline \multirow{2}{*}{$\begin{array}{l}\text { Years }(u) \text { at unprofitable } \\
\text { yield }(U) \text { of } 8 \text { percent }\end{array}$} & \multicolumn{3}{|c|}{$\begin{array}{l}\text { Years }(p) \text { at profitable } \\
\text { yield }(P) \text { of } 30 \text { percent }\end{array}$} & \multicolumn{3}{|c|}{$\begin{array}{l}\text { Years }(p) \text { at profitable } \\
\text { yield }(P) \text { of } 24 \text { percent }\end{array}$} \\
\hline & 3 & 2 & 1 & 3 & 2 & 1 \\
\hline \multicolumn{7}{|c|}{ (A) Loan unpaid over entire period } \\
\hline $\begin{array}{l}1 \\
2 \\
3\end{array}$ & $\begin{array}{l}24 \\
21 \\
19\end{array}$ & $\begin{array}{l}22 \\
19 \\
16\end{array}$ & $\begin{array}{l}19 \\
15 \\
13\end{array}$ & $\begin{array}{l}20 \\
17 \\
16\end{array}$ & $\begin{array}{l}18 \\
16 \\
14\end{array}$ & $\begin{array}{l}16 \\
13 \\
12\end{array}$ \\
\hline
\end{tabular}

(B) Loan repaid in equal periodic installments

$\begin{array}{lllllll}1 & 28 & 26 & 23 & 23 & 21 & 19 \\ 2 & 26 & 24 & 19 & 21 & 19 & 16 \\ 3 & 24 & 22 & 17 & 20 & 18 & 14\end{array}$

average gross yield is 23,21 and 20 percent. Considering the likelihood that only a fraction of a loan with a greater than 3 year maturity will be outstanding when the lower 8 percent ceiling applies and that some original loans made will be repaid entirely within three years, the post-law average gross yields are of a magnitude imposed in some other states and higher than the rates charged by banks. Thus, while the lower gross yields might explain a reduction in the number and riskiness of loans made, it does not appear to be the primary explanation of the demise of the industry. Consequently, I now turn to an analysis of their operating costs.

\subsection{Operating cost analysis}

Operating cost data as reported to the Maine Bank Commissioner were gathered for each year 1960 through $1971 .{ }^{7}$ A cost model was estimated, based on an extensive consideration of the finance company operations presented in

${ }^{7}$ After extensive checking (that proved time consuming, frustrating, and necessary), some of the data had to be rejected for obvious deficiencies in reporting. In particular, a company's first full year of operation and last year of operation were discarded as unrepresentative of normal operating conditions. A description of the sample is presented in Benston (1974b, table 3). 
another paper [Benston (1974a)]. The primary output variable is the number of loans serviced, approximated by the average number outstanding during the year. Other variables are included to account for cost differences among firms that are not related to the primary output. A multiplicative cost function is assumed (from which log-linear regression were run) as follows:

$$
\begin{aligned}
& O C=b_{0} N L O^{b_{1}}(N L M / O)^{b_{2}}(N L L / M)^{b_{3}} D E L 60+{ }^{b_{4}}(N L O / O F)^{b_{5}} L O C A L^{b_{6}} u, \\
& O C= \text { operating costs per year (default losses, interest, and income } \\
& \text { taxes not included), } \\
& N L O= \text { average number of loans outstanding [(number year beginning }+ \\
&\text { number year end) } / 2], \\
& N L M / O= \text { number of loans made per year to number outstanding }(N L O), \\
& N L L / M=\text { number of large (over } \$ 1000) \text { loans made to the total number made } \\
& \times 100+1(1 \text { is added because some companies did not make large } \\
&\text { loans in this event log }[(N L L / M)+1]=0), \\
& D E L 60+= \text { dollars of loans delinquent } 60 \text { days or more per dollar of loans } \\
& \text { outstanding } \times 100, \\
& N L O / O F= N L O \text { per office, } \\
& L O C A L= 10 \text { if the company is local, } 1 \text { if it is national, } \\
& u= \text { error term, where log } u \text { has mean equal to } 0 \text { and is distributed } \\
& \text { independently across units. }
\end{aligned}
$$

'Output' is measured by $N L O ; N L M / O$ measures the rate of growth of a company; $N L L / M$ is an output homogeneity measure which extensive testing of a much larger amount of branch data from three major companies [Benston (1974a)] showed to be the only meaningful distinction of loan size; DEL60+ measures the additional costs of handling delinquencies; NLO/OF measures the economies of scale related to office size rather than company size; and LOCAL measures differences in reported operating costs between local companies that tend to be owner-run and national companies that allocate central company overhead to their Maine operations. Unfortunately, data on loans to new, present, and former borrowers are not reported to the state nor could these data be acquired from a sufficient number of companies.

The cost of servicing a small loan was estimated with multiple regression analysis after all variables were transformed to common logarithms. Regressions were computed for each year individually, 1960 through 1971. Table 2 give the regression coefficients and $t$-values computed for each year. ${ }^{8}$ Notable in the

\footnotetext{
${ }^{8}$ The regressions were tested for conformance with homoscadisticity, linearity, and independence as follows: the data were ordered by the principal independent variable, $N L O$; the residuals were plotted and Durbin-Watson statistics and first-order serial correlation coefficients were computed. These tests indicated the desired conformance.
} 
table are the positive (though not large) coefficients for large loans $(N L L / M)$, positive (though not consistently significant) coefficients for local vs. national companies ( $L O C A L)$, and generally insignificant coefficients for the size of office $(N L O / O F)$.

Table 2

Determinants of total operating expenses regression coefficients ( $t$-values). Dependent variable: total expenses before income taxes, interest and losses. ${ }^{a}$

\begin{tabular}{|c|c|c|c|c|c|c|c|}
\hline \multirow[b]{2}{*}{ Year } & \multicolumn{7}{|c|}{ Independent variables (see description in the text) } \\
\hline & NLO & $N L M / O$ & $N L L / M$ & DEL60+ & NLO/OF & $L O C A L$ & CONST \\
\hline 1960 & $\begin{array}{c}1.18 \\
(8.59)\end{array}$ & $\begin{array}{c}0.65 \\
(1.04)\end{array}$ & $\begin{array}{c}0.020 \\
(1.24)\end{array}$ & $\begin{array}{c}-0.11 \\
(0.67)\end{array}$ & $\begin{array}{c}0.26 \\
(1.37)\end{array}$ & $\begin{array}{c}0.22 \\
(1.80)\end{array}$ & $\begin{array}{c}0.30 \\
(1.60)\end{array}$ \\
\hline 1961 & $\begin{array}{r}1.16 \\
(11.46)\end{array}$ & b & $\begin{array}{c}0.070 \\
(0.83)\end{array}$ & $\begin{array}{c}0.12 \\
(1.13)\end{array}$ & $\begin{array}{c}0.38 \\
(3.12)\end{array}$ & $\begin{array}{c}0.17 \\
(1.97)\end{array}$ & $\begin{array}{c}0.60 \\
(0.65)\end{array}$ \\
\hline 1962 & $\begin{array}{c}1.22 \\
(12.71)\end{array}$ & $\begin{array}{c}0.03 \\
(2.39)\end{array}$ & $\begin{array}{c}0.061 \\
(6.35)\end{array}$ & $\begin{array}{c}0.60 \\
(4.53)\end{array}$ & $\begin{array}{r}-0.02 \\
(0.12)\end{array}$ & $\begin{array}{c}0.22 \\
(2.14)\end{array}$ & b \\
\hline 1963 & $\begin{array}{c}1.10 \\
(8.90)\end{array}$ & $\begin{array}{c}0.74 \\
(2.07)\end{array}$ & $\begin{array}{r}0.044 \\
(4.44)\end{array}$ & (3.39) & $\begin{array}{l}0.27 \\
(1.76)\end{array}$ & $\begin{array}{c}0.22 \\
(1.98)\end{array}$ & b \\
\hline 1964 & $\begin{array}{c}1.15 \\
(4.22)\end{array}$ & b & $\begin{array}{c}0.035 \\
(1.99)\end{array}$ & $\begin{array}{c}0.16 \\
(0.85)\end{array}$ & $\begin{array}{c}0.24 \\
(0.72)\end{array}$ & $\begin{array}{c}0.30 \\
(1.28)\end{array}$ & $\begin{array}{c}0.20 \\
(0.66)\end{array}$ \\
\hline 1965 & $\begin{array}{c}1.30 \\
(9.29)\end{array}$ & $\begin{array}{c}1.30 \\
(4.11)\end{array}$ & $\begin{array}{c}0.067 \\
(5.55)\end{array}$ & $\begin{array}{c}0.23 \\
(1.18)\end{array}$ & $\begin{array}{c}-0.20 \\
(0.99)\end{array}$ & $\begin{array}{c}0.43 \\
(3.69)\end{array}$ & $\begin{array}{c}0.38 \\
(2.15)\end{array}$ \\
\hline 1966 & $\begin{array}{c}1.29 \\
(13.14)\end{array}$ & $\begin{array}{c}0.21 \\
(0.74)\end{array}$ & $\begin{array}{r}0.037 \\
(2.12)\end{array}$ & $\begin{array}{c}0.33 \\
(1.48)\end{array}$ & b & $\begin{array}{c}0.36 \\
(2.38)\end{array}$ & $\begin{array}{c}0.23 \\
(0.82)\end{array}$ \\
\hline 1967 & $\begin{array}{c}1.28 \\
(8.88)\end{array}$ & $\begin{array}{c}0.52 \\
(1.96)\end{array}$ & $\begin{array}{r}0.077 \\
(4.35)\end{array}$ & $\begin{array}{c}0.15 \\
(1.00)\end{array}$ & $\begin{array}{c}-0.09 \\
(0.40)\end{array}$ & $\begin{array}{c}0.39 \\
(2.70)\end{array}$ & $\begin{array}{c}0.15 \\
(0.70)\end{array}$ \\
\hline 1968 & $\begin{array}{c}1.10 \\
(17.45)\end{array}$ & $\begin{array}{c}0.46 \\
(1.33)\end{array}$ & $\begin{array}{c}0.041 \\
(2.42)\end{array}$ & $\begin{array}{c}-0.05 \\
(0.60)\end{array}$ & $\begin{array}{c}0.49 \\
(4.07)\end{array}$ & b & $\begin{array}{c}0.10 \\
(0.31)\end{array}$ \\
\hline 1969 & $\begin{array}{c}1.07 \\
(7.73)\end{array}$ & $\begin{array}{c}0.20 \\
(1.22)\end{array}$ & $\begin{array}{r}0.050 \\
(1.59)\end{array}$ & $\begin{array}{c}-0.19 \\
(1.39)\end{array}$ & $\begin{array}{c}0.42 \\
(1.68)\end{array}$ & $\begin{array}{c}0.13 \\
(0.82)\end{array}$ & $\begin{array}{c}0.16 \\
(0.90)\end{array}$ \\
\hline 1970 & $\begin{array}{c}1.19 \\
(4.55)\end{array}$ & b & $\begin{array}{c}0.055 \\
(1.14)\end{array}$ & $\begin{array}{c}-0.04 \\
(0.16)\end{array}$ & $\begin{array}{c}0.09 \\
(0.19)\end{array}$ & $\begin{array}{c}0.45 \\
(1.35)\end{array}$ & $\begin{array}{c}0.50 \\
(1.60)\end{array}$ \\
\hline 1971 & $\begin{array}{c}1.06 \\
(8.47)\end{array}$ & $\begin{array}{r}-0.20 \\
(1.29)\end{array}$ & $\begin{array}{c}0.016 \\
(0.71)\end{array}$ & $\begin{array}{c}-0.057 \\
(0.63)\end{array}$ & $\begin{array}{c}0.057 \\
(0.32)\end{array}$ & $\begin{array}{c}0.027 \\
(0.26)\end{array}$ & $\begin{array}{c}1.47 \\
(4.13)\end{array}$ \\
\hline
\end{tabular}

${ }^{a} R^{2}$ for any year's regression is no less than 0.96 . Variables were converted to common logarithms for regressions.

${ }^{\mathrm{b}} F$-value too small for inclusion.

\subsection{Economies of scale hypothesis}

The coefficients estimated contradict the hypothesis that consumer finance companies reduced the number of offices to achieve economies of scale. First, the average size of office did not increase over the period: the geometric mean number of loans per office were 367 in 1960, 246 in 1964, 278 in 1967, and 269 in 1970. Second, the insignificant coefficients of the size of office variable $(N L O /$ 
$O F$ ) and the consistently greater than unity (though not statistically significantly greater) coefficients of the scale variable $(N L)$ are contrary to the "economies of scale' hypothesis. ${ }^{9}$

\subsection{Tests of the hypothesis that the maturity limitation makes 'normal' operations unprofitable}

Competing hypotheses about profitability of 'normal' operations were tested by estimating the annual cost of making and servicing a loan compared to the revenue produced by the loan, given the legal ceiling rates. While it may seem that the maximum legal ceiling rate in Maine of 36 percent before 1967 and 30 percent thereafter on small loans is high, the data indicate that operating costs were even higher.

Table 3

Average annual operating cost per loan under $\$ 1000$ (income taxes, interest and default losses not included) assessed at geometric means. ${ }^{a}$

\begin{tabular}{lccl}
\hline & & \multicolumn{2}{c}{ Only variables significant at 0.05 level included } \\
\cline { 3 - 4 } Year & $\begin{array}{c}\text { All variables } \\
\text { included }\end{array}$ & Amount & Variables \\
\hline 1960 & 55.72 & 53.15 & NLO, NLO/OF \\
1961 & 54.73 & 53.44 & NLO, NLO/OF, LOCAL \\
1962 & 62.89 & 62.92 & NLO, LOCAL, NLM/OF, LL/NLM, DEL6O+ \\
1963 & 62.81 & 62.08 & NLO, LOCAL, NLM/OF, LL/NLM, DEL6O+ \\
1964 & 66.48 & 64.63 & NLO, LOCAL, LL/NLM \\
1965 & 76.79 & 72.46 & NLO, LOCAL, LL/NLM, NLM/O \\
1966 & 75.11 & 71.44 & NLO,LOCALLL/NLM \\
1967 & 66.68 & 65.14 & NLO, LL/NLM, NLO/OF \\
1968 & 96.25 & 96.55 & NLO,LL/NLM, NLO/OF \\
1969 & 78.23 & 75.97 & NLO, NLO/OF \\
1970 & 82.08 & 73.54 & NLO, NLO/OF \\
1971 & 105.32 & 68.33 & NLO, CONST \\
\hline
\end{tabular}

${ }^{a} A l l$ variables evaluated at geometric mean values against coefficients given in table 2 , with $L L / N L M$ set equal to one $(\log L L / N L M=0)$. Since operating cost $=O C=b_{0} N L O^{b_{1}}$ $(N L M / O)^{b_{2}}(N L L / M)^{b_{3}}$ etc., setting $N L L / M$ to 1 , average cost $=O C / N L O=b_{0} \overline{N L O}^{b_{1}-1}$ $\overline{(N L M / O)^{b_{2}}}$ etc., where bars denote geometric means. Marginal costs can be calculated by multiplying average cost by $b_{1}$. Since $b_{1}$ is not significantly different from 1 , these calculations are not presented.

Average (and marginal, since these are almost the same) costs of making and servicing loans under $\$ 1000$ were calculated from the coefficients presented in table 2 and the underlying data. The estimates, presented in table 3 , show gener-

${ }^{9}$ Since all the data are in logarithms, the coefficients measure elasticities directly. For example the 1960 coefficient of 1.18 indicates that a 10 percent increase in the number of loans outstanding would on the average result in an 11.8 percent increase in operating costs. 
ally increasing average costs per loan over the period. From 1960 through 1963 costs averaged about $\$ 56$ a loan. From 1964 through 1967, when the ' 36 month limitation' was enacted, they were about $\$ 70$ a loan. For 1968 through 1970 per loan costs averaged about $\$ 82 .{ }^{10}$ In part, the increasing costs mirror changes

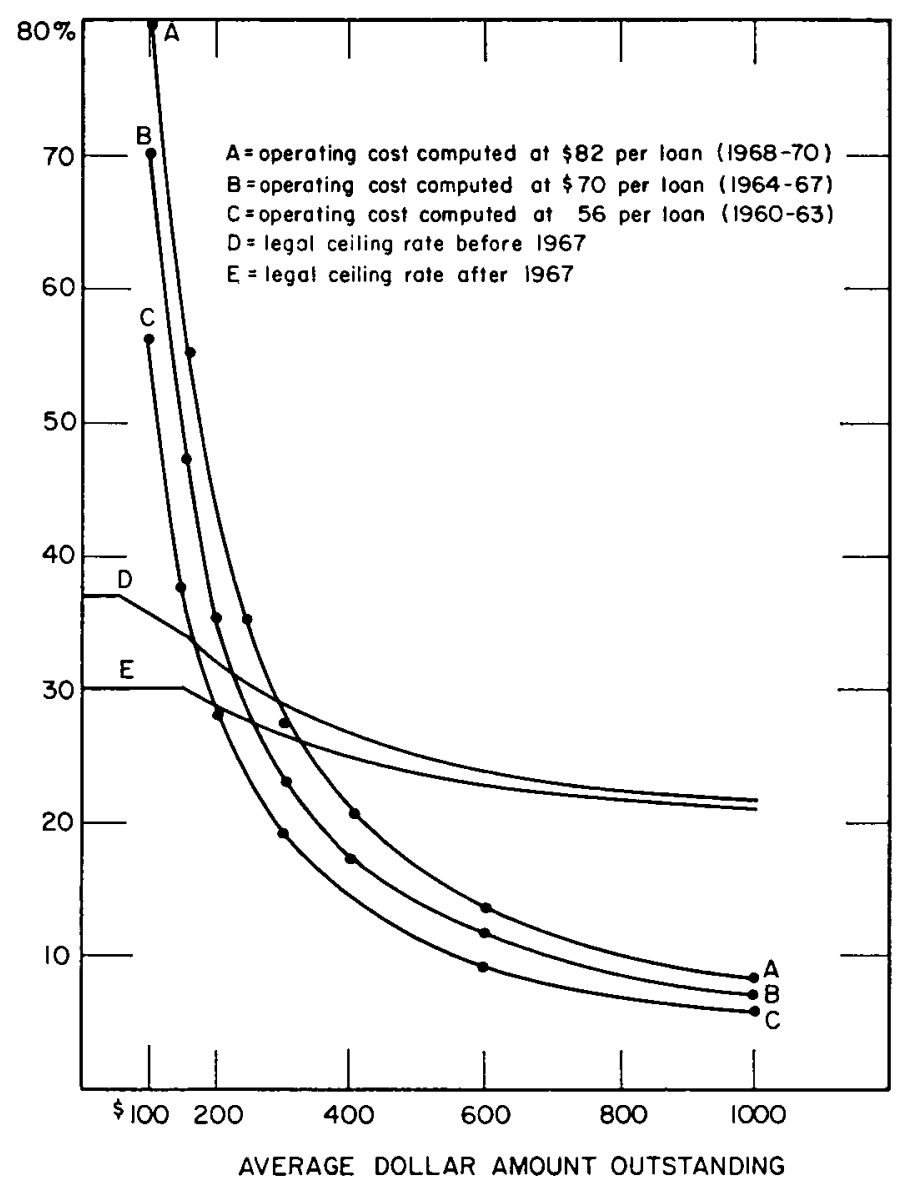

Fig. 2. Average operating costs and legal ceiling rates per dollar of loans.

in the price level. However, the ceiling rates under which the companies operate were not changed to reflect changes in nominal costs. Rather, in 1967, the annual ceiling rate on loans with initial amounts of under $\$ 150$ was reduced from 36 to 30 percent. Fig. 2 shows average annual operating costs expressed as a per-

${ }^{10} \mathrm{It}$ is interesting to note that operating costs per loan in 1968,1969 , and 1970, estimated from data from 124 national companies, averaged \$72 [Benston (1974a)]. 
centage of dollars of loans outstanding, together with Maine's ceiling rates in effect before and after the 1967 law change. It seems clear that even under the higher rates allowed before 1967 , loans under $\$ 150$ probably were not profitable (recall that default losses and interest are not included in the average costs). With the lower ceiling rates the finance companies do not appear able to cover operating costs and interest for loans under about $\$ 500$. Why, then, do they make these loans?

The reason finance companies make apparently unprofitable loans (except when the negative contribution margin becomes too great) is suggested by the description of loan company operations presented above. Unprofitable small

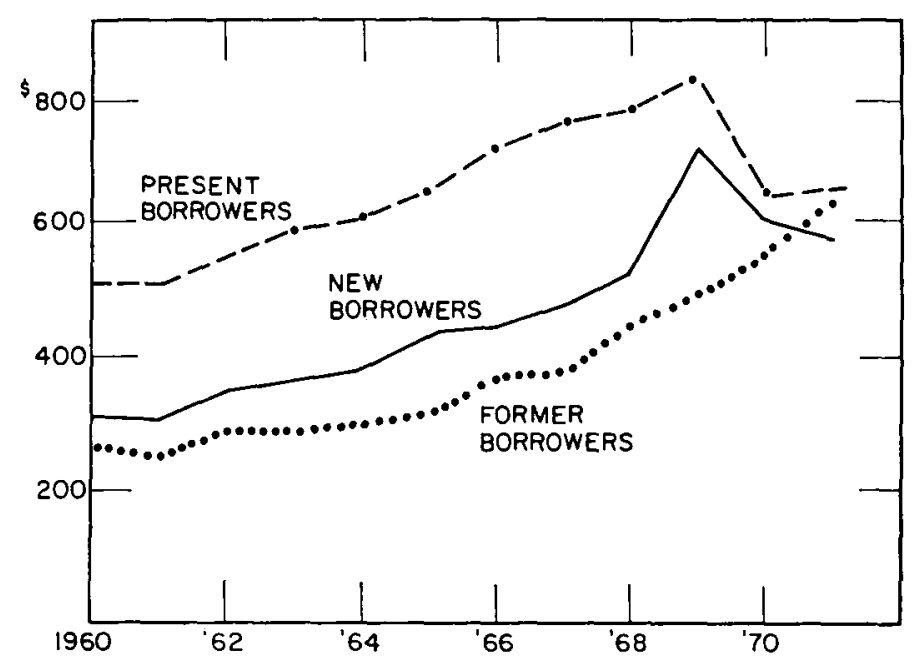

Fig. 3. Average size of loans made to new, present and former borrowers in Maine, 19601971 ; means of averages at three major finance companies.

loans may be made when the company expects that a portion of these customers will renew these loans for larger amounts, primarily by borrowing again before the loan matures. Also, the loan company is able to assess the risk of lending larger amounts by first lending smaller sums. Thus, an initially unprofitable loan may result in a later profitable relationship. As is indicated by the model, the present value of the expected net cash flow from the customer is expected to be positive.

This explanation is consistent with the data. The 1967 reduction in rate ceilings for loans under $\$ 150$ made these very unprofitable. The number of under $\$ 100$ loans made dropped from 13 and 14 percent of total loans made in 1966 and 1967 to 7 and 3 percent of the total in 1968 and 1969 [Benston (1974b, fig. 3)]. But companies still found loans of $\$ 100$ to $\$ 300$ worth making. Until 
1969 , the number of loans made of this size did not change greatly. However, the '36 month limitation', which became operationally effective in 1969, deprived them of the opportunity to engage a customer in a profitable long-term relationship. The effect on the average size of loans made by four major finance companies (from whom data could be obtained), shown in fig. 3 , also is consistent with the implications of the analysis. Loans made to new and former borrowers were consistently smaller than those made to present borrowers. Average amounts for all three types of loans increased over time as inflation reduced the real amount of funds borrowed and as increasing operating and money costs made smaller loans less profitable to the finance companies. In 1969, when the ' 36 month limitation' became effective (and the particular companies whose data are reported realized that the law would not be repealed), the average size of loans made to new borrowers increased sharply from $\$ 482$ in 1967 and $\$ 528$ in 1968 to $\$ 712$ in 1969 . In comparison, the average size of loans made to present borrowers was $\$ 758$ in $1967, \$ 778$ in 1968 and $\$ 822$ in 1969 . As fig. 3 shows, by 1970 and 1971 size of loans made to new, present and former borrowers averaged about the same.

\subsection{Costs of lending to new versus present customers}

The numbers or amounts of loans made to present borrowers are not reported to the Maine authorities. However, comparative differences in the cost of lending to new and former borrowers versus present borrowers were measured in a study of the branch operations of one small and three major consumer finance companies. The methodology and data used, and detailed findings derived, are reported in Benston (1974a). In that study, data from approximately 2600 branches for each of the three years were analyzed. Regressions of direct cash operating expenses (total direct branch expenses not including occupancy, advertising, losses, and interest) were run for each year of each company on output (the average number of loans serviced), cost homogeneity variables (percent of loans made to new borrowers, percent of large [over \$1000] loans made, percent of other than personal loans made, relative factor prices in the county, and whether or not the branch was in a suburb), and market structure and legal variables (concentration ratios, state laws on entry restrictions, and creditors' remedies). The elasticities estimated indicate that an increase in the percentage of loans made to new borrowers from, say, 25 to 30 percent, and an offsetting decrease in the percentage made to present borrowers might result in a 1.6 to 3.2 percent increase in total branch costs for one company, a 0.4 to 1.5 increase for the second, as much as a 4.9 percent increase for the third, and no significant difference for the fourth. The data on former borrowers are not consistent: Two companies' data show operating costs to be lower the higher the percentage of former borrowers, while two reveal higher costs. However, the coefficients estimated are not statistically significant. 
It appears, then, that new borrowers are served at not much higher cost than present or former borrowers, so that even if a finance company made 54 rather than 27 percent of its loans to new customers, its operating costs might increase by only ten percent. Consequently, it does not appear that a law restricting lending to new customers would increase operating costs sufficiently to 'explain' the demise of the small loan companies in Maine.

\subsection{Collection costs and losses}

The effect of the ' 36 month limitation' on collection costs and losses can be illustrated by considering the monthly payments schedule for a loan that provides the borrower with about $\$ 600$. At the present ceiling annual simple interest equivalent rate of 26 percent, the monthly payment for a 12 month loan is $\$ 58$, for a 24 month loan $\$ 32$, and for a 30 month loan $\$ 28 .{ }^{11}$ For about an $\$ 800$ loan, the rate is a bit more than 24 percent and the monthly repayments are $\$ 80$ for a 12 month loan, $\$ 44$ for a 24 month loan, and $\$ 36$ for a 30 month loan. The take-home family income of the average small loan borrower in Maine is between $\$ 475$ and $\$ 550$ a month. ${ }^{12}$ While the borrower normally can make the required payments, a small disaster, such as illness or job layoff, might make it difficult for him to keep up to date. The loan companies recognize the possibility and usually 'work with' the borrower by allowing him to extend his payments, often lending him additional funds to 'tide him over'. Possibly because of this practice, the lost rate actually experienced had been relatively low. Measured as charge-offs or increases to allowances for bad debts less recoveries divided by average dollars of loans outstanding, the net loss rate experienced by Maine consumer finance companies averaged 2.22 percent from 1960 through 1967. (The low was 1.87 in 1962 and the high 2.62 in 1967.)

The lower gross yields allowed by the '36 month limitation' apparently changed the trade-off between higher operating expenses and lower default costs. In 1968 the net loss rate increased to 3.25 percent, in 1969 to 4.10 percent, in 1970 to 7.66 percent and in 1971 (the last year for which data are available) to 8.41 percent. The companies apparently could not require repayment within 36 months without incurring additional losses.

Thus, the analyses support the hypothesis that the ' 36 month limitation' made customary operations by finance companies unprofitable. It appears that (1) the impossibility of extending loans, when the borrower is unable to pay on time with consequent increase in defaults and reduction in revenue from which operating and other costs could be paid, and (2) the impossibility of main-

\footnotetext{
${ }^{11}$ The actual proceeds are adjusted up or down to make the monthly payments equal, even dollar amounts.

${ }^{12}$ Source: Interviews with finance company executives and analysis of survey data presented in section 5 .
} 
taining a long-term customer relationship, were important factors in the decision of finance companies to cease operations in Maine, though the additional cost of lending to new compared to present customers did not appear important. This hypothesis is tested further with an analysis of the companies' profitability before and after the restrictive legislation was effective.

\subsection{Profitability of finance companies}

Those who urged passage of the ' 36 month limitation' and the reduction in ceiling rates argue that the companies could easily withstand the lower revenue. As Governor Curtis said in 1969: 'Indeed, our small loan regulating laws are, and they remain, favorable to small loan concerns.' To provide a test of this contention, the annual yield on assets was computed for each finance company whose data are given above for the years 1960 through 1971. Because the data do not permit an unambiguous measure of yield, two rates were computed: (1) net small loan business operating income before income taxes and interest as a percent of average loans outstanding ${ }^{13}$ (2) net total operating income from all sources before income taxes and interest expense as a percentage of average assets 'used and useful', which includes working capital, furniture and fixtures, etc., in addition to loans receivable. While the returns on equity would have been preferable numbers, the data (particularly those of national companies and unincorporated local companies) do not allow meaningful measures.

The data were disaggregated because some critics believe that national finance companies shift profits from life, accident, and disability insurance to an affiliated or owned insurance company to understate the income data reported to the Bank Commissioner. Mean percentage rates of return on assets are given for local and national companies, for the companies grouped according to asset size (under and over $\$ 1$ million), and for all companies. Fig. 4 presents these data graphically.

Without some standard of comparison, one can only draw definitive conclusions about the data that show a negative rate of return. Nevertheless, unless the reports are in error, it is clear that the net income before income tax and interest expense of most finance companies in Maine after 1969 (when the 1967 law began to take effect) was inadequate to support continued operations. For all companies, small loan operating income, as a percentage of average outstanding loans, dropped from 10.8 percent in 1960 to 6.0 percent in 1967, to 4.6 percent in 1969, and then to 1.7 percent, and 0.08 percent in 1970 and 1971 . The reduction was similar for total net operating income, for local and national, small, medium, and large companies.

\footnotetext{
${ }^{13}$ Income taxes are omitted because they need not reflect current operations and because they are often allocated arbitrarily by national companies. Interest also is often allocated arbitrarily by national companies and is largely a function of the type of financing (debt versus equity, primarily) used.
} 
Turning (with less certainty) to the period before the law, it appears that finance companies' return on assets was reasonably good, considering that they are relatively highly leveraged. However, even before the 1967 law was enacted, their yields were trending downward, as fig. 4 graphically shows. In part, the reduced percentages are explained by the increasing operating costs shown in table 3. Average costs per loan increased from $\$ 55.72$ in 1960 to $\$ 66.68$ in 1967. Interest on the funds they borrowed also increased over the period, ${ }^{14}$
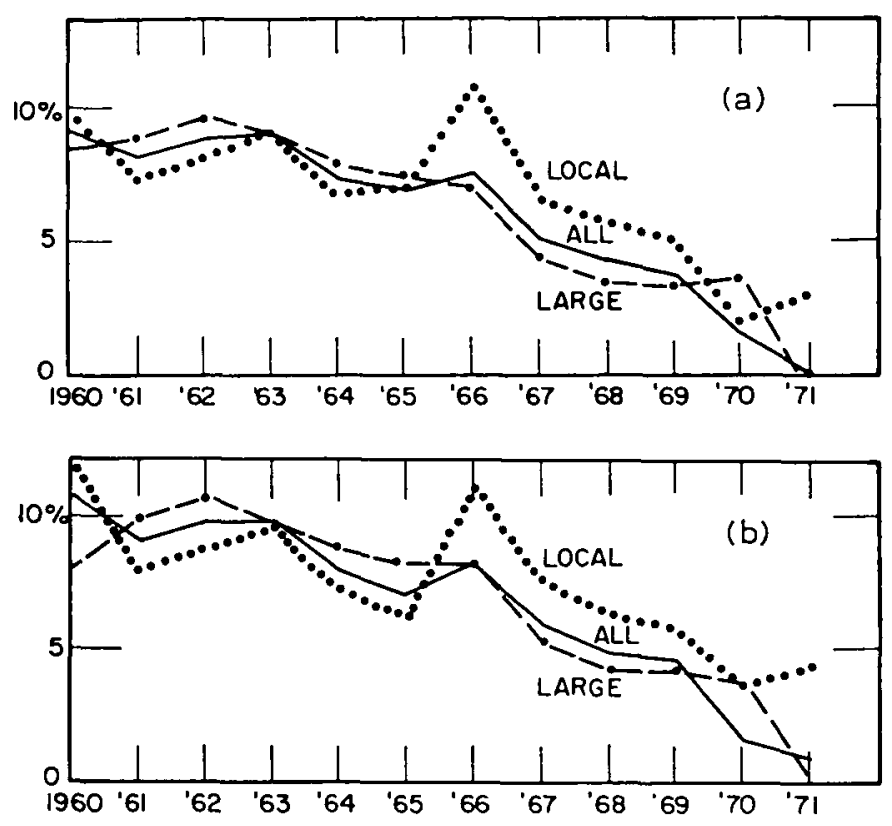

Fig. 4. Net income before income taxes and interest expense; all local and large (assets over $\$ 1$ million) companies [Benston (1974a, tables 6 and 7)]. (a) Small loan net income as percentage of average loans outstanding; (b) total net income as percentage of average assets 'used and useful'.

but the maximum rates companies could charge did not increase. It appears, then, that their rapid exodus from the state was a result of decreasing returns due primarily to the ' 36 month limitation' and secondarily to the reduction in the rate ceiling and maximum loan size. These factors were compounded by greater bad debt losses, largely due also to the ' 36 month limitation'.

\footnotetext{
${ }^{14}$ The annual average rate of finance company paper placed directly, 3 to 6 months, from 1960 through 1971 was 3.54 (1960), 2.68, 3.07, 3.40, 3.83, 4.27 (1965), 5.42, 4.89, 5.69, 7.16, 7.23 (1970), and 4.91 (Federal Reserve Bulletin, various issues).
} 


\section{The effect of the decline in finance companies' lending on the availability of credit to consumers}

\subsection{Description of data}

A large sample of borrowers was interviewed to determine directly the effect of the reduction in finance company lending on their customers. ${ }^{15}$ In November and December, 1971, four major consumer finance companies which were shrinking and/or discontinuing their operations in Maine were asked to supply the names, telephone numbers, addresses, and other information on former or present customers who had wanted to take out or increase loans during the previous four months, but whose requests were refused because the company was not extending or making loans. In all cases, these were people to whom the companies would have been pleased to lend had they not decided to reduce or eliminate their operations in Maine. Names, addresses, and telephone numbers of 771 borrowers were received from the companies.

All borrowers for whom valid telephone numbers could be found were contacted. ${ }^{16}$ In all, 436 persons were contacted at this stage of the survey. The telephone interviews proved very satisfactory, in part because the interviewers were very good at establishing rapport. The principal interviewer was a graduate student at the University of Maine who was familiar with much of the state. After some experimentation, he developed the technique of conducting an apparently unstructured conversation of from four to six minutes, during which he avoided leading the borrowers to answers, yet managed to get replies to most of the questions. When an interviewee wouldn't give information until specific questions were asked and then seemed to be answering to please or get rid of the interviewer, the interview was marked 'refused to respond'. Most in this group include people who simply wouldn't speak to the interviewer. Of the 436 people contacted, 58 (13.3 percent) refused to answer and 378 (86.6 percent) gave the requested information. The interviewers believe that they received valid answers to their questions, with one exception, the question 'What percentage amount of loan was outstanding when you attempted to renew your loan?' Many interviewees gave vague replies which indicated that they either really did not know the amount or did not understand the question.

\footnotetext{
${ }^{15}$ An analysis was made of the supply and demand of consumer loans outstanding in Maine at consumer finance companies, industrial banks, federal and state credit unions, commercial banks and mutual savings banks at each year end, 1965 through 1967. The demand coefficients estimated were used to predict the amount of loans demanded in 1968 through 1971. Though the results are not conclusive, the amount of loans supplied appear to be significantly (though not radically) less than the amounts demanded. See Benston (1974b) for details.

${ }^{16}$ Initially, borrowers were sent a letter that informed them of the study and that they would be contacted by telephone, assuring them that they would not be sold anything, that the information gathered would be kept confidential and that the study might benefit them. The letters appeared to be ignored completely. Consequently this procedure was abandoned.
} 
The 436 borrowers contacted represent 56.6 percent of the sample. It would be potentially misleading to assume that the persons not contacted are like those contacted; the absence of locatable telephone numbers might be an indication that inability to borrow additionally from the finance companies put them in a particularly difficult financial situation. Consequently, a sub-sample of 82 (24.2 percent) of the 335 borrowers not contacted was selected. (The sub-sample comprised all borrowers in several towns.) The last known home and work addresses of these borrowers was obtained, from which all were located (eventually) and interviewed, although this proved quite time-consuming. Thus a control against the 235 persons not contacted was established.

The principal question the borrowers were asked was whether or not they had obtained elsewhere the funds for which they had gone to the finance companies. To ascertain which characteristics were associated with ability or inability to get funds, data on the borrowers were obtained from the finance companies, as follows: occupation, weekly gross salary, age, marital status, number of dependents, number of years the borrower was continuously in debt to the finance company, and the number of previous loans with the finance company. ${ }^{17}$

The data were used first to determine whether or not the 460 borrowers contacted (67.2 percent) are representative of the entire sample of 771 . Chisquare statistics, were computed from two-way comparisons of the samples. The chi-square statistics show no significant differences (at the 5 percent level) in any of the characteristics measured between the people who answered the initial telephone survey (A) and those who refused (R), between the A group and those who were contacted by field interviews (C), and between the $C$ group and those not contacted $(\mathrm{N})$. Only those who answered the initial survey (A) and those not contacted $(\mathrm{N})$ showed significant differences. The most striking differences are: those not contacted $(\mathrm{N})$ include a slightly higher percentage of unskilled and much higher percentage of professional workers, they earn somewhat less on average, a higher percentage of them are single, and they have fewer dependents than the A group. ${ }^{18}$ Of greatest interest for this study is the fact that the groups do not differ much in number of years in debt or number of previous loans. Consequently, it is concluded that the 460 borrowers interviewed, on which the balance of this section is based, represent well the entire sample of 771 .

\subsection{Ability to borrow and source of funds of individuals surveyed}

Table 4 shows that close to half the borrowers obtained funds $(O)$ from other sources and half did not obtain new funds $(N O)$. This table also shows that of those people who were able to borrow, most wanted the money to consolidate

\footnotetext{
${ }^{17}$ The price at which loans were obtained was not asked, since all finance companies charge the legal maximum.

${ }^{18}$ See Benston (1974b, tables 10,11 and 13) for details.
} 
debts (54.5 ' $O$ ' versus 48.9 percent ' $N O$ ') or buy a used car (19.5 ' $O$ ' versus 12.7 ' $N O$ '). Among people who did not obtain funds, the percentage wanting to purchase furniture and household items was highest (10.0 ' $N O^{\prime}$ 'versus 5.6 percent ' $O$ '). People who wanted to borrow for 'socially acceptable purposes', i.e., to pay medical bills, make home improvements, or pay school expenses, were about evenly divided, ' $O$ ' versus ' $N O$ '. There seems no evidence that those who did not obtain funds wanted the money for obviously 'less worthy' purposes.

Each of the seven characteristics reviewed above, plus the percent of loan unpaid at the time the borrower wanted additional funds, and reason for borrow-

Table 4

Primary reason for original borrowing: Obtained $(O)$ and not obtained (NO) new funds.

\begin{tabular}{lrr}
\hline Percentages & \multicolumn{1}{l}{$O$} & NO \\
\hline Consolidate debts & 54.5 & 48.9 \\
Used car & 19.5 & 12.7 \\
Medical bills & 7.4 & 8.7 \\
Furniture and household items & 5.6 & 10.0 \\
Home improvements & 5.2 & 4.8 \\
School related expenses & 2.6 & 3.5 \\
Miscellaneous & 5.2 & 11.4 \\
& $\underline{100.0}$ & $\underline{100.0}$ \\
& $\underline{ }$ & \\
& 231 & 229 \\
Number of borrowers & 12.78 & \\
$\quad$ Chi-square & & \\
$\quad$ (at 5\% level, 6 degrees of freedom $=12.60)$ \\
\hline
\end{tabular}

ing, were examined to determine what distinguished those who obtained funds $(O)$ from those who did not $(N O)$. This examination and the chi-square statistics computed revealed that the only significant difference between the $O$ and the NO former finance company customers is the 'reason for borrowing' (see table 4). ${ }^{19}$ Thus (contrary to expectations), the explanation of why some people did and some did not obtain funds is not discernable from the data collected. The interviewers were unable to say whether the people who did not borrow

\footnotetext{
${ }^{19}$ The chi-square statistics for the other characteristics are reported in Benston (1974b). None is significant at the 5 percent level. Eisenbeis and Murphy (1974) subjected these data to a multivariate analysis. They also added variables for 'sex' and 'ethnic' factors (French surname) to test for the possibility of discrimination. They concluded '... the multivariate analysis of successful and unsuccessful borrowers in this study supports Benston's work. That is, in terms of the characteristics that were available and which are typically used in credit scoring models, there does not seem to be a systematic relationship between denials and the measures reflecting credit worthiness.'
} 
tried to borrow but were refused, could not find another institution in their area from which to borrow (such as a credit union), gave up trying after being told that the finance company would not advance them funds ('if they wouldn't lend to me, who would?'), or bought more goods on credit but did not consider this 'borrowing'.

Those who obtained funds were queried about the source. Most (39.8 percent) shifted their debt to another finance company, which shows that the ' 36 month limitation' was not entirely effective. Banks provided loans to 32.9 percent, 20.8 percent borrowed from a credit union, and 6.5 percent from other sources. None said they borrowed from an unlicensed lender.

Those who did not obtain funds took one of three actions. Most continued to pay regularly (77.3 percent). Only one person ( 0.4 percent) declared bankruptcy. The balance missed some payments but were paying off or had paid off the loan (22.3 percent). ${ }^{20}$

In summary, these data support the tentative conclusion that other lenders did not completely replace the loans that would have been made by the finance companies. More specifically, the interviews indicate that half of the former 'good' finance company customers did not obtain the funds they wanted and 40 percent of those who did obtain funds got them from another finance company. ${ }^{21}$ Unfortunately, nothing is known about the source (if any) of funds for people who would have been first time borrowers from finance companies.

Of course, some 'consumer advocates' argue that most of the former longterm finance company customers were now 'out of the companies' clutches' because they couldn't or didn't borrow additional funds or borrowed from another source. The characteristics of these debtors whom these consumer advocates want to protect are analyzed next.

\section{Long- and short-term borrowers - Characteristics and relationship with bankruptcy}

An important motivation (among 'consumer advocates' at least) behind the enactment of the ' 36 month limitation' is the belief that long-term borrowers need protection from the finance companies and from themselves. In-depth psychological, economic, and sociological studies of long-term borrowers would be desirable to determine whether the legislation is, in fact, wanted by and

\footnotetext{
${ }^{20}$ The interviewees also were asked how they felt about not having been able to borrow from their customary finance company. Seventy-five percent of those who obtained funds and fifty-five percent of those who did not felt 'better off'. A detailed analysis of the data is given in Benston (1974b).

${ }^{21}$ Some interviewees indicated that some finance companies evaded the law by means of a simple subterfuge. The borrowers were told to pay off their loan with a check that would not be deposited until they had obtained another loan at another (suggested) finance company. Data on aggregate finance company loans indicate that this practice was not widespread [see Benston (1974b, fig. 6)].
} 
helpful to them. Unfortunately, such studies are not only very expensive to make, but difficult to interpret. However, the economic and other measurable characteristics of long-term borrowers can be compared to those of shorter-term borrowers to determine what characterizes those people who are presumed to need protection. Data on the sample of borrowers described above are used for this analysis.

\subsection{Characteristics of long- and short-term borrowers}

In percentage terms, the finance company customers surveyed on whom additional data were available (383 observations) were previously in debt to the company the following number of years: 1 year, 13 percent; 2 to 4 years, 42 percent; 5 to 8 years, 20 percent; 9 to 12 years, 16 percent; and $13+$ years, 10 percent. With respect to number of loans previously held, the percentages are: 1., 23 percent; 2 to 4,34 percent; 5 to 8,21 percent; and $9+, 21$ percent. Thus, most of these people were in debt continuously to finance companies for much longer than the 36 months the law allows.

Tables were prepared and chi-square statistics computed to determine differences in the characteristics of long- and short-term borrowers. ${ }^{22}$ Years of previous indebtedness and number of previous loans were compared with their occupation, salary, age, marital status, number of dependents, reason for wanting original loans, ability to obtain funds, and reaction to not being able to borrow from their customary finance company. Only 'age' revealed a chisquare statistic significant at the 5 percent level. Not surprisingly, a high proportion of borrowers (relative to their number in the sample) who were previously in debt only one year or who had only one previous loan were under 34 years of age. And among borrowers in debt thirteen or more years or with nine or more previous loans, most were in the 45 to 64 age bracket. The number of previous loans and years in debt of the other age groups were in approximate proportion to their distribution in the sample.

Although the chi-square statistics indicate no other 'significant' differences in the other characteristics, examination of the tables [presented in Benston (1974b)] reveals some interesting facts. Long-term borrowers (those continuously in debt for 9 or more years $=C D$, or those who had 9 or more previous loans $=P L)$ tend to be skilled workers $(C D$ and $P L)$, people who make $\$ 200$ or more per week $(P L)$, between 45 and 64 years of age $(C D$ and $P L)$, people with no dependents $(C D$ and $P L)$, and borrowers who wanted the money to consolidate debts $(P L)$. The long-term borrowers appear not to be professional workers $(C D)$, people making less than $\$ 80$ a week $(P L)$, and those under 34 years of age ( $C D$ and $P L$ ). Very-long-term debtors (those in debt continuously for 13 or more years) include fewer than expected borrowers with three or more

\footnotetext{
${ }^{2} 2$ These tables and analyses are presented in Benston (1974b).
} 
dependents and those who wanted money for medical bills, furniture, and home improvements. Short-term debtors (those continuously in debt for less than four years $=C D$, or with one previous loan $=P L$ ) tend to be unskilled workers ( $C D$ and $P L$ ), people earning less than $\$ 80$ a week $(P L)$, those under $24(C D)$ or $34(P L)$, married borrowers $(C D$ and $P L)$, people with five or more dependents ( $C D$ and $P L$ ), and those whose primary reason for borrowing was to pay medical bills $(C D$ and $P L)$. Further, short-term borrowers appear not to be skilled, semi-skilled workers, or white collar workers ( $C D$ and $P L)$, to make over $\$ 161$ a week $(P L)$, to be between 45 and 64 years of age (CD and $P L)$, to be unmarried people, or to have one or no dependents ( $C D$ and $P L)$.

In my opinion, the portrait of the long-term borrower that emerges from the data reviewed is not consistent with the view that they are a homogeneous group who are ill-equiped to handle their financial affairs. Rather their occupations, salaries, marital status, number of dependents, and stated reasons for borrowing show that they are diverse. Only age is significantly (and obviously) related to previous indebtedness. Further, the data suggest that the relationship between borrowers' characteristics and whether they are short- or long-term debtors is consistent with the view of borrowers as rational consumers whose debts reflect their economic and family positions and need for credit. As a further test of whether long term indebtedness is 'bad' for consumers and/or society, the relationship between such borrowing and bankruptcies is considered next.

\subsection{Long-term borrowing and bankruptcy}

Concern over the number of personal bankruptcies filed in Maine was an important reason for the enactment of the '36 month limitation'. In a speech supporting the legislation on April 5, 1967, State Senator Peter Mills said:

The real question, however, is why do people become so indebted that they cannot meet their monthly payments and, therefore, are compelled to file bankruptcy. The main reason for this is the:

(a) high cost of credit,

(b) on unreasonable large indebtedness,

(c) for long periods of time.

The Federal Referee in Bankruptcy for the Southern District of Maine, Mr. Richard Poulos (who strenuously and effectively supported the restrictive legislation), also considered long-term indetedness an important cause of bankruptcies, ${ }^{23}$ perhaps because he comes in direct and frequent contact with those who declare bankruptcy and with their creditors.

\footnotetext{
${ }^{23}$ See last sentence of quote above.
} 
Aside from the important philosophical (and empirical) question of whether bankruptcy is detrimental to consumer welfare, the preliminary question to be answered is whether long-term indebtedness is associated with (or a causal factor of) bankruptcies. Some data on this question were gathered by Referee Poulos from 351 bankruptcy cases on file as of June 13, 1972, in which a particular finance company was the principal creditor. Poulos's staff analyzed the available files and determined the number of times the loan in question had previously been rewritten (with or without an additional cash advance). This

Table 5

Number of times loan was previously rewritten at a large finance company.

\begin{tabular}{|c|c|c|c|c|}
\hline \multirow{2}{*}{$\begin{array}{l}\text { Number of } \\
\text { rewrites }\end{array}$} & \multicolumn{2}{|c|}{ Cases in bankruptcy } & \multicolumn{2}{|c|}{ Good customers } \\
\hline & Number & Percentage & Number & Percentage \\
\hline 0 & 2 & 2.2 & 0 & 0.0 \\
\hline 1 & 59 & 65.6 & 17 & 14.0 \\
\hline 2 & 13 & 14.4 & 18 & 14.9 \\
\hline 3 & 2 & 2.2 & 11 & 9.1 \\
\hline 4 & 1 & 1.1 & 4 & 3.3 \\
\hline 5 & 3 & 3.3 & 9 & 7.4 \\
\hline 6 & 1 & 1.1 & 6 & 5.0 \\
\hline 7 & 1 & 1.1 & 4 & 3.3 \\
\hline 8 & 1 & 1.1 & 6 & 5.0 \\
\hline 9 & 1 & 1.1 & 3 & 2.5 \\
\hline 10 & 1 & 1.1 & 7 & 5.8 \\
\hline 11 & 2 & 2.2 & 1 & 0.8 \\
\hline $12+$ & 3 & 3.3 & 35 & 28.9 \\
\hline \multirow{3}{*}{$\begin{array}{l}\text { No } \\
\text { information }\end{array}$} & 90 & 99.8 & 121 & 100.0 \\
\hline & 261 & 290.0 & 116 & 95.9 \\
\hline & 351 & & 237 & \\
\hline
\end{tabular}

determination could be made for 90 of these loans. Table 5 gives the number and percentage of the rewrites of this total compared to similar data, from the same company, of borrowers who were included in the sample above. It is clear from table 5 that the people who declared bankruptcy had renewed their loans far less often than those who were considered good customers by the finance company and who, when credit was cut off, did not declare bankruptcy. Thus, the available data runs contrary to the belief that such long-term indebtedness is a causal factor of bankruptcy. Rather, as several studies have shown, bankruptcy appears related to harsh wage garnishments and unexpected costly medical problems, job losses and marriage failures. ${ }^{24}$

${ }^{24}$ See Stanley and Girth (1971) and Shuchman and Jantscher (1972). 


\section{Summary and conclusions}

This study analyzes legal restrictions on the length of time during which people may borrow from relatively high interest rate lenders - finance companies. The arguments for and against such legislation are based, in large measure, on alternative hypotheses about the operations of finance companies, on the effect of the law on the availability of credit, and on the desire to protect long-term borrowers. An opportunity to test these hypotheses occurred when Maine passed legislation in 1967 that imposed on finance companies a ceiling rate of 8 percent simple interest on loan balances outstanding for more than 36 months.

There were 28 finance companies in Maine just before the legislation was enacted, and they had 116 offices. By June 30, 1972, the total had dropped to 9 companies and 24 offices. Loan dollars outstanding declined from $\$ 31.0$ to $\$ 10.8$ million. The companies' gross earnings were affected, but the major effect was on their operating costs. Empirical analysis of finance company operations shows that the cost of processing loans makes those under about $\$ 300$ to $\$ 400$ unprofitable. Since first time borrowers tend to borrow such small amounts, the companies count on the larger, profitable loans taken when customers renew or add to their initial loans. In addition, finance companies depend on loan extensions to allow a borrower who is 'in trouble' to pay out his debt. These factors explain why finance companies cannot operate profitably with the ' 36 month limitation' in force. The data analyzed also show that finance companies do not experience economies of scale, did not consolidate their operations, and probably ceased operations because their rates of return declined to the point where no other course was sensible. Thus, the data analyzed are inconsistent with the 'consumer advocates' hypotheses 1, 2, 3 and 4 given in section 2 above. The data also are inconsistent with the finance companies' hypotheses 1 and 2, but support their hypothesis 3 . The major finding, though, was not suggested by the proponents of the legislation. It appears that the major effect of the legislation is that it restricts finance companies from engaging in profitable long-term borrower relationships in which unprofitable first time loans serve as 'loss leaders'.

Individual borrowers were interviewed to determine the effect of the finance companies' radical decline in lending. The sample consisted of 518 former finance company borrowers who wanted to borrow additionally from the companies in 1970 but were turned away because the companies were closing their operations. Half of these 'good' customers did not obtain funds elsewhere. Forty percent of those who did obtain funds borrowed from other finance companies. All of those who did obtain funds paid off their loans, some with difficulty. An analysis of the characteristics (occupation, salary, age, dependents, etc.) of those who did and did not obtain funds revealed no significant differences. Thus the data do not support the belief of the 'consumer advocates' who 
claimed borrowers were served without the finance companies, since only half those who wanted to borrow and to whom the finance companies would have loaned obtained the desired funds.

The occupations, etc., of long-term debtors were compared to those of short-term debtors to determine what characterizes the people whom the legislation was designed to protect. Not surprisingly, 'age' is the only significantly different (at the five percent level) factor - long-term debtors are middle aged, short-term debtors are young. However, the systematic (though not statistically significant) differences associated with short- and long-term indebtedness are consistent with the view that long-term indebtedness is a function of the usual demands and resources of consumers. Finally, the hypothesis that long-term indebtedness with finance companies leads to bankruptcy was tested and rejected.

The conclusion of this analysis is that legislation that restricts the term of finance company loans to consumers drives these lenders out of the market and hence limits the availability of funds to consumers. This limitation appears unjustified and unfair to consumers who would prefer the services offered by finance companies or who have no other legal alternative.

\section{References}

Benston, G.J., 1974a, The costs to consumer finance companies of extending consumer credit, in: National Commission on Consumer Finance, Technical studies II (U.S. Government Printing Office, Washington, DC) 1-158.

Benston, G.J., 1974b, An analysis of Maine's ' 36 month limitation' on finance company small loans, in: National Commission on Consumer Finance, Technical studies II (U.S. Government Printing Office, Washington, DC) 1-63 (pages are renumbered).

Eisenbeis, R. and N.B. Murphy, 1974, Interest rate ceilings and consumer credit rationing: A multivariate analysis of a survey of borrowers, Southern Journal of Economics 41, 115-123.

Poulos, R.E., undated, Proposed revisions for the treatment of uncontrovertable claims, in Ch. XIII proceedings, unpublished paper.

Shuchman, P. and G.R. Jantscher, 1972, Effects of the federal minimum exemption from wage garnishments on non-business bankruptcy rates, Commerical Law Journal 77, 360-363.

Stanley, D.T. and M. Girth, 1971, Bankruptcy: Problem, process, reform (The Brookings Institution, Washington, DC).

Taeusch, C.F., 1942, The concept of 'usury': The history of an idea, Journal of the History of Ideas 3, 291-318. 